\title{
Overvektige mødre gir overvektige barn
}

\section{Mors vekt før svangerskapet og vektøkningen under svangerskapet påvirker barnets kroppsmasseindeks ved treårsalderen.}

I en ny delstudie fra Den norske mor og barnundersøkelsen ble kroppsmasseindeks for rundt 31000 treåringer undersøkt (1). Etter internasjonale kriterier for overvekt var $12 \%$ av dem overvektige og $2 \%$ hadde fedme. Av

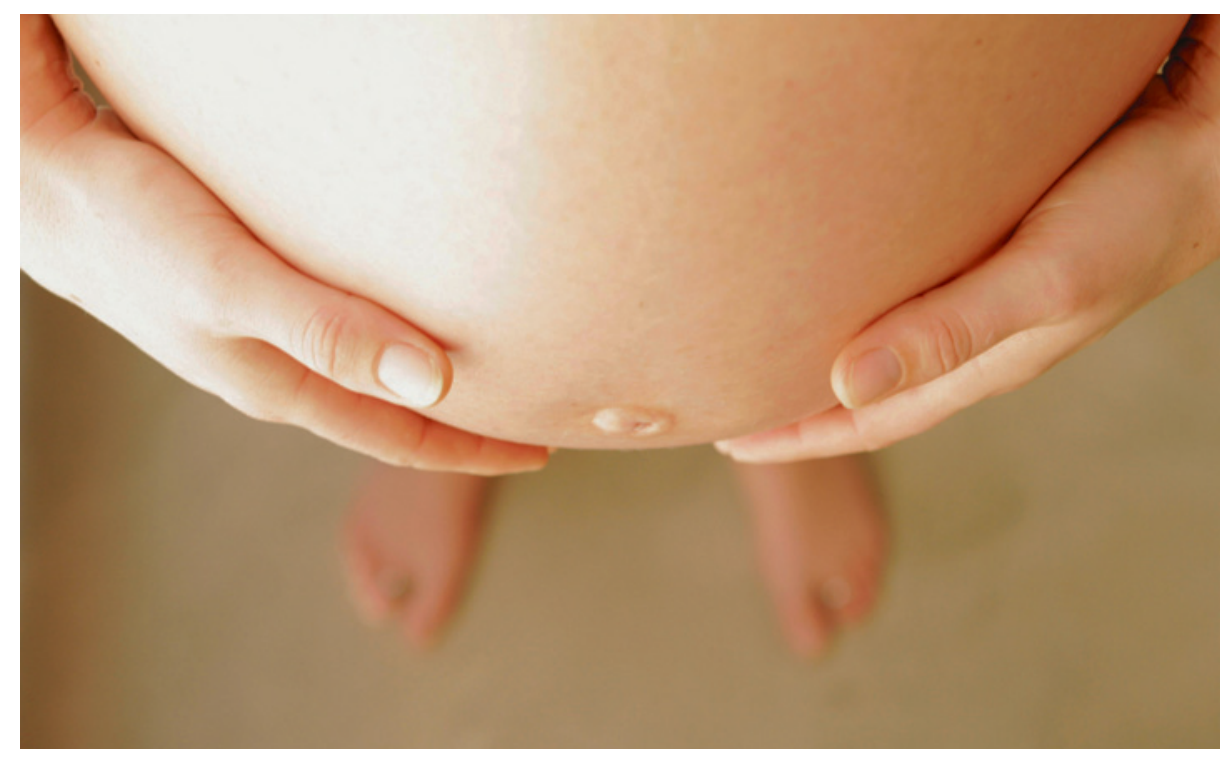

Illustrasjonsfoto Thinkstock

\section{Diagnosen påvirkes av sosial status}

\section{Diagnosen en pasient får er ikke bare avhengig av symptomene.}

Sosial ulikhet i helse er godt dokumentert. Lav sosioøkonomisk status henger bl.a. sammen med lavere levealder og høyere risiko for sykdom.

Hittil har hovedtyngden av forskningen for gitt. Når sykdom først er oppstått, antas det at den gis en diagnose som reflekterer symptomene, ikke sosioøkonomisk status. Vi ønsket å se om det også er en sammenheng mellom sosial status og selve diagnostiseringen (1). Vår antakelse var at en diagnose er en tolking av symptomer - og jo mer diffus sykdommen eller symptomene er, desto større er innslaget av sosial og kulturell tolking. Vi valgte dermed diffuse musom sosiale ulikheter og helse tatt diagnosene mødrene hadde $66 \%$ normal kroppsmasseindeks (BMI) før svangerskapet, mens 31\% hadde $\mathrm{BMI}>25$, dvs. overvekt/fedme. Gjennomsnittlig vektøkning første 30 uker av svangerskapet var på $9,0 \mathrm{~kg}$.
For hver enhet økning i BMI før svangerskapet økte barnets BMI ved tre år med $0,035 \mathrm{~kg} / \mathrm{m}^{2}$. Dette innebærer at mødre med BMI 35 i gjennomsnitt hadde barn med 0,5 enheter høyere BMI ved treårsalderen sammenliknet med mødre med BMI 20. Vektøkning i svangerskapet påvirket i seg selv risikoen for overvekt hos barnet uansett mors vekt før hun ble gravid. Vektøkning hadde størst effekt når BMI før svangerskapet var høy. Det ble ikke funnet sikre effekter på barnets vekt av amming, mors røykevaner, medievaner eller utdanningsnivå. teret gjennom mors vekt og vektøkning øker risikoen for senere overvekt, og at økende forekomst av overvekt hos kvinner kan forsterke fedmeepidemien i neste ledd. Kohorten følges videre for å studere om effektene er de samme også ved senere alder. Å holde en sunn vekt før og i svangerskapet er viktig, understreker forfatterne.

\section{Ketil Størdal}

ketil.stordal@fhi.no

Nasjonalt folkehelseinstitutt

Litteratur

1. Stamnes Køpp UM, Dahl-Jørgensen K, Stigum H et al. The associations between maternal prepregnancy body mass index or gestational weight change during pregnancy and body mass index of the child at 3 years of age. Int J Obes (Lond) 2012 36: $1325-31$
Funnene tyder på at overernæring av fos-

høyt utdannede mer enn to ganger høyere enn for dem med lavest utdanning (kontrollert for sektor).

Funnene utfordrer den tradisjonelle forståelsen av hvordan sosioøkonomiske faktorer bidrar til skjev sykdomsfordeling i befolkningen. I tillegg til faktorer som f.eks. trekk ved jobben eller livsstil bør selve diagnostiseringen studeres mer for å få bedre forståelse av årsakene til sosial ulikhet $\mathrm{i}$ helse.

\section{Berit Bringedal}

berit.bringedal@legeforeningen.no

Legeforeningens forskningsinstitutt med høy utdanning, og dersom de jobber i helsesektoren. Oddsen for at en person som er ansatt i helsesektoren får diagnosen diffus psykisk sykdom, er $56 \%$ høyere enn om vedkommende jobber i teknisk sektor (kontrollert for utdanning). Tilsvarende er oddsen for en diffus psykiatrisk diagnose blant

\section{Litteratur}

1. Bringedal B, Tufte PA. Social and diagnostic 40: $656-62$. inequality in health. Scand J Public Health 2012; 